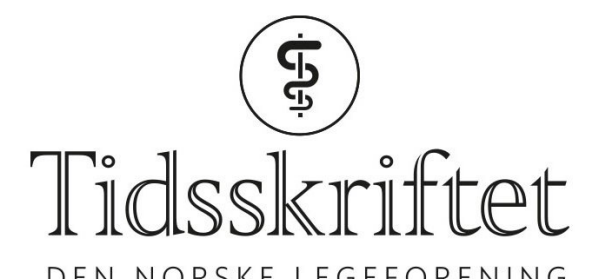

DEN NORSKE LEGEFORENING

\title{
Norsk militær sanitet før og nå
}

ANMELDELSER

RUNE RIMSTAD

Avdelingsleder medisin og helsefag, Oslo universitetssykehus

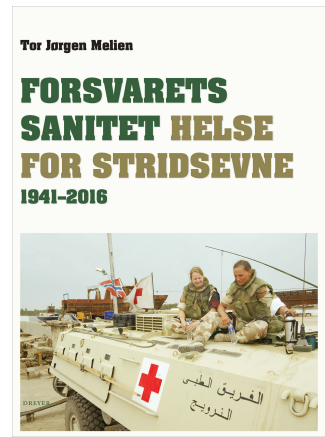

Tor Jørgen Melien

Forsvarets sanitet

Helse for stridsevne 1941-2016. 517 s, ill. Oslo: Dreyers forlag, 2016. Pris NOK 399

ISBN 978-82-8265-175-2

Denne historiske fremstillingen av Forsvarets sanitet ble gitt ut i forbindelse med 75årsjubileet i 2016. Den følger også den øvrige saniteten i Forsvaret, den sivile helsetjenesten og det vekslende samspillet mellom disse. Forfatteren er historiker og offiser.

Innledningsvis omtales forskningsstatus på feltet - med Marinens og Hærens sanitet fra middelalderen til starten av den annen verdenskrig som bakgrunn. Den videre fremstillingen er delt i tre: annen verdenskrig, den kalde krigen og perioden 1990-2016. For hver av disse er det ett kapittel om utviklingen i perioden, ett om Forsvarets sanitet, ett om saniteten i Forsvaret og ett om militære operasjoner. Forfatteren vektlegger organisasjon, kompetanse, personell og materiell for å analysere utviklingen. Det hele avsluttes med en epilog ved sjefen for Forsvarets sanitet.

Dette er en lettlest fremstilling med god språklig flyt, rikt illustrert, men vekslingen mellom ulike temaer gir mindre flyt i boken som helhet. De ulike delene kan godt leses alene. Solid innbinding gjør at den blir tung å ta med på reise.

Forsvarets sanitet vil først og fremst være av interesse for dem som har et forhold til saniteten fra før, det trenger ikke være mer enn avtjent tjeneste, enten det er befalsskole, tjeneste som sanitetssoldat, krigskirurgikurs eller annet. Ikke så rent få leger har hatt slik tjeneste og vil kjenne seg igjen i beskrivelsen av akkurat den perioden, det tjenestestedet eller den våpengrenen. Boken vil kunne sette leserens personlige erfaringer i en sammenheng som 
på en interessant måte skaper refleksjon rundt ens egen rolle.

Den samlede historiske fremstillingen er fyldig i forhold til annen litteratur om norsk militær sanitet. Den har en klar faglig innretning, med angivelse av metode og mål og en diskusjon av egne begrensninger. Beskrivelsene av den generelle medisinske utviklingen $\mathrm{i}$ perioden blir noe overfladisk, den militærmedisinske utviklingen er bedre gjengitt. Jeg savner et konkluderende kapittel.

Boken gir verdifull innsikt i den historiske bakgrunnen for dagens sanitetstjeneste og totalforsvarskonseptet, der den militære og den sivile helsetjenesten må fungere sammen som én enhet i krise og krig. Den kan bidra til å skape en forståelse som gir bedre samarbeid og synliggjøre at militær sanitet ikke er noe som kun er relevant for Forsvaret.

Publisert: 19. mars 2018. Tidsskr Nor Legeforen. DOI: 10.4045/tidsskr.17.1067 (C) Tidsskrift for Den norske legeforening 2020. Lastet ned fra tidsskriftet.no 